\title{
Spinal Musküler Atrofi (SMA) ve Tibbi Beslenme Tedavisi
}

\section{Spinal Muscular Atrophy (SMA) and Medical Nutrition Therapy}

\author{
Mücahit Muslu1 ${ }^{1}$
}

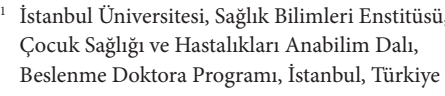

ORCID: M.M. 0000-0002-8761-5061

Sorumlu Yazar/Corresponding Author: Mücahit Muslu,

İstanbul Üniversitesi, Sağllk Bilimleri Enstitüsü, Çocuk Sağlığı ve Hastalıkları Anabilim Dalı, Beslenme Doktora Programı, İstanbul, Türkiye E-posta: dytmuslu@gmail.com

Geliș tarihi/Submitted: 03.11.2020 İlk revizyon/First Revision Received: 15.01.2021 Son Revizyon/Last Revision Received: 09.02.2021 Kabul Tarihi/Accepted: 30.03.2021

Atıf/Citation: Muslu M. Spinal muscular atrophy (SMA) and medical nutrition therapy. Sağlık Bilimlerinde İleri Araştırmalar Dergisi 2021; 4(3): 131-140.

https://doi.org/10.26650/JARHS2021-820357
ÖZ

Spinal musküler atrofi hastalığı dört farklı tipi bulunan nöromusküler bir hastalıktır. Hastalığın tedavisinde ilaç ve gen tedavisi gibi yöntemler kullanılmakla beraber kanıtlanmıs net bir tedavi bulunmamaktadır. Tedavi genel olarak hastalığın semptomlarını kontrol altına almaya dayanmaktadır. Beslenme sorunlarının başında yutma güçlüğü, gastroözofageal reflü ve gastrointestinal disfonksiyon gelmektedir. Hastalık tiplerine göre değișen bu sorunlar hastanın büyüme ve gelişimini olumsuz etkilediği gibi diğer semptomları tetikleyerek hastanın yaşam kalitesini düşürmektedir. Beslenme sorunlarının önlenmesi ve hastalı̆̆ın yönetimi için hastanın semptomlarına göre bireyselleştirilmiş tıbbi beslenme tedavisi büyük önem taşımaktadır. $\mathrm{Bu}$ tedavi, multidisipliner bir ekip tarafindan hazırlanmakta ve uzman diyetisyenler tarafindan takip edilmektedir. Tibbi beslenme tedavisi yönetimi detaylı anamnez alımı, antropometrik, kimyasal ve laboratuvar bulgularının değerlendirilmesi, enerji ve besin ögeleri gereksinimlerinin hesaplanması, uygun beslenme yolunun seçilip uygulanması, yakından takip ve değerlendirme şeklinde yapılmaktadır. Bu süreçte hastanın enerji gereksinimi hesaplanırken hastalar için geliştirilmiş özel formüllerin kullanılması önerilmektedir. Hastalarda uygulanabilecek diyet çeşitleri ve diyetin içeriği üzerine yapılmış çalışmalar oldukça sınırlıdır. Tibbi beslenme tedavisinde temel yaklaşım diyetisyen tarafından yakın takip ile antropometrik ve biyokimyasal bulgulara dayanarak diyetinin düzenlenmesi ve kontrolüne dayanmaktadır. Hastalarda optimal beslenmenin gerekliliklerinin belirlenebilmesi için acil olarak iyi planlanmış ileri çalışmalara ihtiyaç duyulmaktadır.

Anahtar Kelimeler: Spinal musküler atrofi, Tibbi beslenme tedavisi, Beslenme

\section{ABSTRACT}

Spinal muscular atrophy disease is a neuromuscular disease with four different types. Although methods such as drug and gene therapy are used in the treatment of the disease, there is no proven treatment. Treatment is generally based on controlling the symptoms of the disease. Difficulty in swallowing, gastroesophageal reflux and gastrointestinal dysfunction are the leading nutritional problems. These problems, which vary according to the disease's type, affect the growth and development of the patient negatively and reduce the patient's quality of life by triggering other symptoms. Medical nutrition therapy, individualized according to the patient's symptoms, is of great importance for the prevention of nutritional problems and the management of the disease. This treatment is prepared by a multidisciplinary team and followed by expert dietitians. Medical nutrition therapy management is carried out in the form of detailed anamnesis, evaluation of anthropometric, chemical and laboratory findings, calculation of energy and nutrient requirements, choosing and applying the appropriate nutrition route, close monitoring and evaluation. In this process, it is recommended to use special formulas developed for patients while calculating the patient's energy requirement. Studies on the types of diet that can be applied to patients and the content of the diet are quite limited. The basic approach in medical nutrition treatment is based on close follow-up by the dietician and the regulation and control of the diet based on anthropometric and biochemical findings. Well-planned further studies are urgently needed to determine the requirements for optimal nutrition in patients. Keywords: Spinal muscular atrophy, Medical nutrition therapy, Nutrition 


\section{GİRIŞ}

Spinal musküler atrofi (SMA), ilerleyici kas atrofisi, zayıflı̆̆ı ve felci ile omurilikteki alfa motor nöronların dejenerasyonu ile karakterize olan genellikle otozomal resesif geçişli bir grup nöromusküler hastalığı içermektedir (1). SMA hastalığında başlangıç yaşı veya motor nöron fonksiyonlarına göre çok çeşitli fenotipler görülmektedir. Ulusal SMA Birliği hastalığı dört gruba ayırmıștır. Bu gruplar SMA Tip 1 (ağır form), SMA Tip 2 (ara form), SMA Tip 3 (hafif form) ve SMA Tip 4’tür (2,3). Bebek ölümlerinin önde gelen genetik nedenlerinden biri olan SMA, dünya genelinde yaklaşık 11.000 yenidoğandan birini etkilemektedir (1). Tanı almış tüm bebeklerin yaklaşık olarak \%58'inin SMA Tip 1, \%29'unun Tip 2 ve \%13'ünün Tip 3 geliştireceği bildirilmiştir (4). $\mathrm{Bu}$ hastalığın en yaygın formu olan SMA Tip 1, 5q11.2-q13.3'e lokalize olmuş survival motor nöron (SMN) 1 genindeki homozigot mutasyonun veya delesyonun neden olduğu türdür (5). Survival motor nöron 1 genindeki bu kusurlar, omuriliğin ön boynuz hücrelerinin ve beyin sapının alfa motor nöronlarının seçici olarak yok edilmesine neden olmaktadır(6) . Survival motor nöron 1 geni dişında bu gen ile neredeyse özdeş bir gen olan SMN 2 geni de mevcuttur. Hastalığın ciddiyeti büyük ölçüde SMN 2'nin kopya sayısına bağlıdır ve daha düşük kopya sayısı daha şiddetli bir fenotip ile ilişkilidir (7). Bunun yanında bazı istisnalar ve farklı genetik etkiler bulunmaktadır (8).

SMN 1 genindeki mutasyon sonucunda yutma ve beslenme güçlüklerine ve solunum yolu enfeksiyonlarına yol açabilen kas atrofisi ve zayıflığı oluşmaktadır. Hastalığının tiplerine göre hastalık semptomları değişmekte ve tedavi yönetimi hastalığın tiplerine göre planlanmaktadır. SMA hastalık tipleri ve genel özellikleri Tablo 1'de gösterilmektedir $(2,3)$. Hastalığın klinik bulgularının farklılık göstermesi hastaya göre multidisipliner bir tedavinin uygulanmasını gerektirmektedir. Prognozu olumsuz etkileyen durumların saptanması, hastaların yakından takibi ve zamanında tedavilerinin yapılması hastaların yaşam kalitesini arttırmaktadır (9).
Tablo 1. SMA türleri ve özellikleri $(2,3)$

\begin{tabular}{|c|c|c|c|c|}
\hline Tip & $\begin{array}{c}\text { Hastalık } \\
\text { İsmi }\end{array}$ & $\begin{array}{c}\text { Başlan- } \\
\text { gıç }\end{array}$ & $\begin{array}{c}\text { Ambulasyon } \\
\text { Durumu }\end{array}$ & Prognoz \\
\hline Tip-1 & $\begin{array}{l}\text { Werd- } \\
\text { nig-Hoff- } \\
\text { mann }\end{array}$ & $<6$ ay & $\begin{array}{l}\text { Bağımsız otura- } \\
\text { mayan hastalar }\end{array}$ & $\begin{array}{c}\text { Yaşam } \\
\text { beklentisi } \\
2 \text { yıldan } \\
\text { fazla değil- } \\
\text { dir }\end{array}$ \\
\hline Tip-2 & Dubowitz & 6-18 ay & $\begin{array}{l}\text { Dik oturabilen } \\
\text { ancak ayakta } \\
\text { duramayan } \\
\text { hastalar }\end{array}$ & $\begin{array}{c}\text { Yaşam } \\
\text { beklentisi } \\
\text { yaklaşık } \\
\text { 2-20 yıldır }\end{array}$ \\
\hline Tip-3 & $\begin{array}{l}\text { Kugel- } \\
\text { berg-We- } \\
\text { lander }\end{array}$ & $>18$ ay & $\begin{array}{l}\text { Hastalar genel- } \\
\text { likle ambulasyo- } \\
\text { na ulaşır }\end{array}$ & $\begin{array}{c}\text { Yaşam } \\
\text { beklentisi } \\
\text { etkilenmez }\end{array}$ \\
\hline Tip-4 & $\begin{array}{l}\text { Yetişkin } \\
\text { Tip }\end{array}$ & $>18$ yaş & $\begin{array}{l}\text { Hastalar bağım- } \\
\text { sız yürüyebilir }\end{array}$ & $\begin{array}{c}\text { Yaşam } \\
\text { beklentisi } \\
\text { etkilenmez }\end{array}$ \\
\hline
\end{tabular}

SMẢnın şu an için kesin bir tedavisi bulunmamaktadır. Farmakolojik tedavide kullanılan ilk ve tek ilaç Aralık 2016'da Amerika Gıda ve İlaç İdaresi (FDA) tarafından ve Haziran 2017'de Avrupa İlaç Ajansı (EMA) tarafindan onaylanan ve Spinraza ismi ile satılan Nusinersen'dir. Nusinersen intratekal olarak enjekte edilen bir antisens oligonükleotid olup işlevsel bir SMN proteininin üretimini arttırmak için SMN 2'yi modüle etmektedir (10). Yapılan çalışmalarda Nusinersen'in SMA Tip 1'li hastalarda ve 10 yaşından küçük ayakta olmayan SMA Tip 2 ve SMA Tip 3 hastalarında etkin olduğu gösterilmiştir (11-13). Ayrıca FDA tarafından 2019'da onaylanan ve 2 yaş altındaki hastalarda tek seferlik intervenöz olarak uygulanan Zolgensma gen tedavisi bulunmaktadır (14).

SMA için Bakım Standardı Uluslararası Konferansı 2007'de dünya çapında yaygın olarak kullanılan SMA bakım standartları konusunda bir protokol yayınlamıştır. Bu protokol ortopedik ve pulmoner rehabilitasyon, beslenme tedavisi ve palyatif bakım gibi konuları içermektedir. Mevcut SMA hastalık yönetimi, komplikasyonları azaltmaya ve yaşam kalitesini iyileştirmeye odaklanan destekleyici ve multidisipliner bakıma dayanmaktadır. Pulmoner hastalık, SMA Tip-1 ve Tip 2'de başlıca ölüm nedenidir. Bundan dolayı tedavide solunum sıkıntılarını engellemek oldukça önemlidir. Ayrıca kas güçsüzlüğüne bağlı olarak gerçekleşen beslenme sorunları hastal1ğın gidişatını olumsuz etkilediğinden büyüme ve 
gelişme geriliğine neden olabilmektedir (3). Erken yaşlarda semptom gösteren bebeklerde ve Tip 1'de diğer tiplere göre daha fazla büyüme geriliği gözlemlenmektedir. $\mathrm{Bu}$ nedenle erken semptom gösteren hastalarda optimal büyümenin sağlanması için hızlı bir şekilde tıbbi beslenme tedavisinin başlanılması gerekmektedir (15). Bu derlemenin amacı SMA hastalarının optimal beslenmenin sağlanması, semptomların hafifletilmesi, yaşam kalitesinin arttırılması ve sağlık durumunun iyileştirilmesi için bireyselleştirilmiş tıbbi beslenme tedavisini ve yönetimini güncel kaynaklar ile tartışmak ve beslenme uzmanlarına yol göstermektir.

SMA Hastalarında Beslenmenin Genel Durumu

SMA Tip 1 hastası 11 palyatif bakım alan ve 5 Nusinersen tedavisi alan toplam 16 bebeğin incelendiği bir çalışmada palyatif bakımdaki bebeklerin tümünde yutma sirasında yorgunluk, \%72'sinde gereksinim miktarını alamama, \%55'inde artan beslenme seansları, \%91'inde aspirasyon, \%64'ünde yemek yerken solunum sıkıntısı görülmüştür. Nusinersen tedavisi alan bebeklerde ise ilaç başlangıcında daha iyi bulgular varken daha sonrasında (8-12 aylıkken) 5 bebekte de beslenme sorunlarının tekrar başladı $\breve{g}_{1}$ yalnız motor fonksiyon skorunun iyileştiği bildirilmiştir (16). İngiltere ve İtalya'da yapılmış iki kohort çalışmasında toplamda 146 SMA Tip 2 hastası incelenmiş ve 88 (\%60) hastada ileri beslenme güçlüğü yaşandı̆̆ı görülmüştür. Hastaların 82’sinde (\%60) zayıflık ve 36 'sında (\%25) ileri zayıflık bildirilmiştir (17). Yaşları 2-12 olan \% 28'i Tip 1, \% 45’i Tip 2 ve \% 27'si Tip 3 olan 60 SMA hastasının ileriye dönük incelendiği çalışmada 3 yıl içinde katılımcıların \%47’sinin vücut kütle indeksi z skorlarında düşüş gözlenirken, şiddetli beslenme yetersizliğinin prevelansının \%2'den \%17’ye yükseldiği görülmüştür. Beslenme tüpü yoluyla enteral beslenme alan çocuklarda aşırı beslenme \%29'iken yetersiz beslenme \%35 olarak bildirilmiştir. Aynı zamanda hastaların sadece \%35'inde optimal D vitamini alımı görülmüştür (18). Çin'de 69'u SMA Tip 2, 17'si SMA Tip 3 olmak üzere 86 çocuğun antropometrik ölçümleri ve 24 saatlik diyet alım kayıtlarının incelendiği bir çalışmada ço- cukların diyet alımları Çin Beslenme Referans Alımları ile karşılaştırılmıştır. SMA Tip 2 hastalarının enerji alımları referans değerlere yakın bulunurken Tip 3 hastalarının alımı referans değerlerin altında bulunmuştur. Ayrıca iki grupta da protein alımları referans değerlerin üstündeyken kalsiyum alımları referans değerlerin altında bulunmuştur (19). Yaşlar1 3-45 arasında olan 60 Tip 2 ve 48 Tip 3 SMA hastasının incelendiği çalışmada beslenme ve yutma güçlüğü olan hastaların, bu problemleri olmayanlara göre anlamlı olarak daha yüksek zayıflık ve aspirasyon pnömonisi oranlarına sahip olduğu bulunmuştur (20). Çalışmalarda görüldüğü gibi ilaç kullananlarda dahil olmak üzere SMA hastalarının tüm türlerinde beslenme sorunları görülmektedir. Beslenme sorunları malnutrisyon, obezite, makro ve mikro besin yetersizliği gibi etkilerle hastalığın yönetim sürecini ve hasta ile bakıcısının yaşam standardını olumsuz etkilemektedir. Bu nedenle SMA hastalarında tıbbi beslenme tedavisi hastalığın yönetiminde büyük önem taşımaktadır.

\section{Tıbbi Beslenme Tedavisi ve Yönetimi}

SMA hastalığında çocukların büyüme ve gelişmesinin sağlanması, yaşam kalitesinin artması aynı zamanda solunum yolu sıkıntılarının engellenmesi için tıbbi beslenme tedavisi önem taşımaktadır. $\mathrm{Bu}$ tedavinin multidisipliner bir şekilde yürütülmesi ve bu alanda uzman diyetisyenlerden destek alınması gerekmektedir $(21,22)$. Çocuklarda tıbbi beslenme tedavisi yönetimi; detaylı anamnez alımı, antropometrik, kimyasal ve laboratuvar bulgularının değerlendirilmesi, enerji ve besin ögeleri gereksinimlerinin hesaplanması, uygun beslenme yolunun seçilip uygulanması, yakından takip ve değerlendirme şeklinde yapılmaktadır (23).

\section{Anamnez Alma}

Bebeğin kişisel bilgileri, yakınmaların öyküsü, prenatal, perinatal ve postnatal dönemi kapsayan öykü, geçirdiği hastalıklar, büyüme ve gelişme durumu, beslenme durumu, beslenme davranışları ve bakıcının gözlemlerini kapsamaktadır (24). SMA hastalarında uygulanacak tedavi hastanın bulgu ve semptomlarına göre kişiselleştirilmiş olmaktadır. $\mathrm{Bu}$ 
nedenle anamnezin detaylı alınması hastaya yaklaşım ve tedavinin etkinliği açısından büyük önem taşımaktadır (3)

\section{Vücut Kompozisyonunun Değerlendirilmesi}

SMA hastası çocuklarda çeşitli beslenme sorunları nedeniyle enerji, protein ve çeşitli mikro besin ögesi alımlarının daha düşük olduğu buna bağlı olarak da malnutrisyonun yaygın görüldüğü bilinmektedir (18). Hasta çocukların normal çocuklara göre yağsız vücut kütlesi daha düşükken vücut yağ oranının daha yüksek görülmektedir. Bu nedenle malnutrisyonun yanında obezite de bu hastalar için risk oluşturmaktadır (25). Özellikle enteral yoldan beslenme ile beslenen çocuklarda aşırı beslenme gözükebilmektedir (18). Ayrıca kas gücü azalmasına bağlı olarak bazal metabolizma hızında ve fiziksel aktivitede azalma nedeniyle kilo artışı gerçekleşebilmektedir (26). Hastaların kas hacmi ve kas kalitesi hastalığın tipi ve klinik durum ile ilişkilidir. Genel olarak bakıldığında sağlıklı çocuklara göre daha düşük düzeydedir (27). Aynı zamanda düşük kemik yoğunluğu, düşük $25 \mathrm{OH}$ vitamin D seviyeleri, artmış kemik erimesi belirteçleri ve çok genç hastalarda da asemptomatik vertebra kırıkları görülmektedir (28). SMA hastalarında vücut kompozisyon durumu ve etkileri tam olarak aydınlatılamamıştır. Tedavi sürecinde hastaların optimal beslenmesi hastalığın prognozu için oldukça önemlidir (29). Dual enerji X-1ş1nı absorbsiometri, vücut kompozisyonunun altın standart ölçüsüdür ve yürüyemeyen çocuklarda kemik mineral yoğunluğu ile ilgili anlamlı veriler sağlamaktadir (30).

\section{Gereksinimlerin Hesaplanması}

SMA'da hem enerji hem de besin ögesi gereksinimleri hakkında detaylı bilgi bulunmamaktadır. Dinlenme metabolizma hızı (DMH), sağlıklı akranlara kıyasla SMA'da daha düşük görülmektedir. Ayrıca bu farklılıklar SMA hastaları arasında da görülmektedir (31). Toplam 30 SMA hastasının (15 Tip 1 ve 15 Tip 2) incelendiği bir çalışmada Tip 1 çocukların Tip 2'lere göre daha düşük z skoruna ancak benzer toplam yağ kütlesine sahip olduğu gözlemlenmiştir. Bu çalışma, tek başına z skor ölçümlerinin, özellikle SMA Tip 1'de gereksinimlerin hesaplanmasında yanıltıcı olabileceğini göstermektedir. Vücut kompozisyonlarındaki farklılıklar beslenme dışında nörofonksiyonel bozukluklardan da kaynaklanmaktadır (32). Farklı bir çalışmada da 8 SMA hastası incelenmiş hepsinin referans değerlerden daha yüksek yağ yüzdesine sahip olduğu görülmüştür. Motor fonksiyon, SMA Tip l'de vücut kitle indeksi ve yağsız kütle indeksi ile orta derecede korelasyon gösterirken ve Tip 2'de yağsız kütle indeksi ile zayıf korelasyon göstermiştir (33). Bu nedenle, yalnızca antropometrik verilere dayanan tahmini enerji formüllerinin bu popülasyonda sınırlı değeri olabilmektedir. Vücut kompozisyonunun ve bazal metabolizma hızının göz önüne alındığı bireyselleştirilmiş gereksinimler hesaplanmalıdir (30).

Enerji gereksinimi hesaplaması için altın standart indirek kalorimetredir. Yalnız indirek kalorimetre çoğu klinikte bulunmadığı için rutinde çok kullanılmamaktadır. Bu nedenle sağlık uzmanları çeşitli formülleri kullanmaktadır. SMA hastaları için tahmini enerji denklemleri geliştirmek üzere 122 çocuk ile yapılan güncel bir çalışmada Dünya Sağlık Örgütü (WHO) ve Schofield denklemlerinin bu hastalarda bazal metabolizma enerjisini tam olarak tahmin etmek için yeterli olmadığı bulunmuştur. Spontan solunum hastalarında WHO ve Schofield denklemleri, Nusinersen ile tedavi edilen spontan nefes alan hastalarda Schofield denklemi ihtiyaca daha yakın bulunmuştur. SMA hastaları için geliştirilen enerji gereksinimi formülleri Tablo 2'de verilmiştir (34). Bu çalışma sonucunda ventilasyona bağlı olup olmama, Nusinersen tedavisi alıp almama, vücut ağırlığı, sırtüstü uzunluk ve tibia uzunluğu parametreleri kullanılarak SMA Tip 1 hastaları için dinlenme metabolizma hızı hesaplayan bir web sitesi geliştirilmiştir (35).

SMA Tip 1 hastası çocukların kalori alımının normal çocukların kalori alımının \%67'si kadar olduğu gösterilmiştir. Bu nedenle SMA hastalarının gereksinimleri sağlıklı çocuklardan farklı olabilmektedir. Ayrıca büyüme ve gelişme takibinde standart büyüme ve gelişme eğrileri kullanımı yanlış değerlendirmelere neden olabilmektedir. Bu nedenle hastalar üzerinde daha fazla çalışma yapılarak gereksi- 
Tablo 2. SMA Tip 1 hastaları için geliştirilen DMH hesaplama formülleri (34)

\begin{tabular}{|c|c|}
\hline Hastanın Durumu & Geliştirilen DMH Formülüi \\
\hline \multirow{3}{*}{$\begin{array}{l}\text { Solunum desteği almayan } \\
\text { hasta }\end{array}$} & $\mathrm{DMH}(\mathrm{kcal} /$ gün$)=35 \mathrm{x}$ vücut ağırlı̆̆ $(\mathrm{kg})+75$ (nusinersen tedavisi varsa $)+219$ \\
\hline & DMH $(\mathrm{kcal} /$ gün $)=6 \mathrm{x}$ sirtüstü uzunluk $(\mathrm{cm})+75($ nusinersen tedavisi varsa $)+10$ \\
\hline & DMH $(\mathrm{kcal} / g u ̈ n)=24 \times$ tibia uzunluğu $(\mathrm{cm})+97($ nusinersen tedavisi varsa $)+179$ \\
\hline $\begin{array}{l}\text { Mekanik ventilasyona bağlı } \\
\text { hasta }\end{array}$ & $\mathrm{DMH}(\mathrm{kcal} /$ gün$)=14 \mathrm{x}$ tibia uzunluğu $(\mathrm{cm})+200($ nusinersen tedavisi varsa $)+190$ \\
\hline
\end{tabular}

nimlerin belirlenmesi ve hastalık için özel büyüme eğrilerinin oluşturulması önerilmiştir (36). Aynı zamanda tam aydınlatılamamış olsa da hastalarda metabolik yolaklarda farklılıklar olmaktadır. Özellikle farelerde yapılan çalışmalarda karbonhidrat ve yağ metabolizmalarının değiştiği ve dislipidemi ile karaciğer steatozuna yatkınlığın arttığı görülmüștür. Farelerde uygulanan düşük yağlı diyetlerin hayatta kalım süresini arttırdığı bildirilmiştir $(37,38)$. SMA hastaları için belirlenmiş spesifik besin ögesi gereksinimleri bulunmamaktadır. Columbia Üniversitesi SMA Araştırma Merkezi’nin önerdiği enerji ve besin ögesi gereksinimleri ve açıklamaları Tablo 3'de gösterilmektedir (39).

\section{Beslenme Yolunun Seçimi}

SMA hastalarında besin alımları değişkenlik göstermektedir. Bir yaşına kadar oral alımını sürdüren hastalar olduğu gibi erken zamanda gastrostomi yapilan hastalar da bulunmaktadır (40). Hastalarda beslenme yolu seçimi multidisipliner değerlendirme sonucu bireysel olarak seçilmektedir. Oral alımı iyi olan hastalarda beslenme desteklenirken yetersiz olan hastalarda enteral beslenme başlanmaktadır. Reflü gibi sorunlar nedeniyle nazogastrik tüp kullanamayanlarda ise gastrostomi başlanmaktadır (21). Yapılan bir çalışmada 62 SMA Tip 2 hastası incelenmiş 26 hastanın besin takviyesine ihtiyaç duyduğu ve 15 hastaya gastrostomi yapıldığı görülmüştür. Gastrostomi nedenleri arasında aspirasyon riski (\% 40), yetersiz beslenme ( $\% 47)$ ve solunum veya gastrointestinal problemler (\% 20) yer almıştır (41). İngiltere’de 72 Tip 2 hastasının incelendiği çalışmada ise kilo kaybı, orofaringeal disfaji veya aspirasyon nedeniyle enteral beslenme uygulanmıştır. Gastrostomi yerleştirilen hastaların \%96'sında komplikasyon görülmemiş ve bu hastaların \%66'sına Nissen fundoplikasyonu yapılmamıştır. Gastrostomiden sonra hastaların \%80'inde göğüs enfeksiyonları ve \%84'ünde beslenme durumunun iyileşme gösterdiği bildirilmiştir (42). Çalışmalarda görüldüğü gibi SMA hastalarının beslenmesinin sağlanmasında enteral beslenme büyük önem taşımaktadır.

\section{Hastalarda Beslenme Sorunları}

SMA hastalarında kabızlık, gecikmiş mide boşalması ve gastroözofageal reflü dahil olmak üzere gastrointestinal disfonksiyon, mortalite ve morbiditenin önemli belirleyicilerindendir. Aynı zamanda yutma disfonksiyonu ve reflü solunum sıkıntılarının artmasına neden olmaktadır. Bu durum farmakolojik olarak prokinetik ajanların ve asit nötralleştiricilerin

Tablo 3. SMA hastaları için önerilen enerji ve besin ögesi gereksinimleri ve açılamaları (39)

\begin{tabular}{|c|c|}
\hline Enerji & $\begin{array}{l}\text { Her bir boy uzunluğu başına } 9-11 \mathrm{kcal}(9-11 \mathrm{kcal} / \mathrm{cm}) \\
\text { İdeal olarak enerji alımı izlenmeli 5. ve 10. persentil arasında boya göre ağırlık korunmalıdır. } \\
\text { Tip } 2 \text { ve } 3 \text { hastalığı olan daha yaşlı SMA hastalarından elde edilen verilere göre, beden kütle indeksi } 5 . \\
\text { percentil olan çocukların 50. percentil yağ kütlesi bulunmaktadır. Bunun nedeni, SMA hastalarında } \\
\text { yağsız kütle miktarı önemli ölçüde azalmıştır. }\end{array}$ \\
\hline Protein & $\begin{array}{c}\text { Vücut ağırlığı başına 1-2 gramdır }(1-2 \mathrm{~g} / \mathrm{kg}) \\
\begin{array}{c}\text { Uzun bir süre boyunca } 2 \text { gram/kg/gün'den fazla protein, potansiyel olarak böbrek problemlerine neden } \\
\text { olabilir ve kemik yoğunluğunu olumsuz yönde etkileyebilir. }\end{array}\end{array}$ \\
\hline Yağ & $\begin{array}{l}\text { Toplam kalorinin \%30'u yağlardan gelecek şekilde olmalıdır. } \\
2 \text { yaşından küçük çocuklar, normal beyin gelişimi için esansiyel yağ asitleri sağlanmalıdır. }\end{array}$ \\
\hline Karbonhidrat & Protein ve yağdan sonra geri kalan enerji karbonhidrattan sağlanmalıdır. \\
\hline Lif & Yaş artı 5 'tir ( 3 yaşında bir çocuk günde $3+5=8$ gram life ihtiyaç duyar) \\
\hline $\mathrm{Su}$ & ml/kg'dir. Ateşi olan çocuklar bazı durumlarda daha fazlasına ihtiyaç duyabilir. \\
\hline
\end{tabular}


kullanımını ile kontrol altına alınabilmektedir. Ağır vakalarda gastroözofageal reflüyü azaltmak için laparoskopik Nissen fundoplikasyonu ve gastrostomi uygulanmaktadır (30). Beslenmeye bağlı sorunlar hastalık tiplerine göre değişkenlik göstermektedir. En fazla sorun Tip 1'de gözlenmektedir (3). Yapılan bir çalışmada 11 SMA Tip 1 hastası incelenmiş altıncı aydan sonra yutma bozukluklarının başladığı görülmüştür. Hastaların yutma fonksiyonu değişikliklerinin birbirinden oldukça farklı olduğu bildirilmiştir. Çalışma hastalara yaklaşımın kişiselleştirilmiş olması gerektiğini vurgulamıştır (39). Tip 2 ve Tip 3 hastalarında yapılan bir çalışmada hastaların \%30,6’sında yutma güçlüğü ve boğulma, \%20 ,4'ünde besinin ağza taşınmasında güçlük ve $\% 20$ ,4’ünde çiğneme güçlüğü olduğu belirtilmiştir (20). Farklı bir çalışmada ise Tip 2 hastalarının \%28'inde çiğneme güçlüğü, \%30’unda ağız açmada güçlük, \%25'inde yutma güçlüğü bulunmuştur (22). Katı besinlerde sıvılara kıyasla yutma güçlüğünün daha fazla olduğu gösterilmiştir (43). Maksimal ağız açıklığının, artan disfaji ve boğulma riski ile ilişkili olduğu bildirilmiştir. Bu nedenle maksimal ağız açıklığının değerlendirilmesi, yutma ve beslenme güçlüğü aç1sından yüksek risk altında olan hastaları belirlemek için basit bir teknik olarak hizmet edebilmektedir (17).

Beslenme veya yutma problemi olan hastalarda ortak özellikler arasında oturamama, zayıf baş kontrolü ve mekanik ventilasyon yer almaktadır. Bu sorunlar malnutrisyon ve yüksek aspirasyon riskinin temel nedenleridir. Mevcut motor nöron durumunun beslenme için bağımsız bir risk faktörü olduğu vurgulanmıştır (22). Bunun dışında hastalarda yağ ve karbonhidrat metabolizmasındaki değişikliklere bağlı uzun süreli açlık sonrası hipoglisemi oluşabilmektedir. Bu nedenle hastaların uzun süre aç kalmaması gerekmektedir $(44,45)$. Beslenme güçlüklerinin psikososyal etkisi de oldukça yüksektir. Yemekler aileler için önemli bir sosyal aktivitedir. Çocukların yemek yeme üzerinde kontrollerini kaybettikleri durumlarda kendilerinin ve ailelerinin yaşam kalitesini olumsuz etkilenmektedir (30).

Hastaların beslenme konusunda sıkıntı yaşama- maları için yutma fonksiyonlarının detaylı incelenmesi gerekmektedir. Yutma problemi olan hastaların yutma rehabilitasyona alınması gerekmektedir (46). Bu hastalarda hastanın yutabileceği kıvamda besinler hazırlanmaktadır. Aynı zamanda az az ve sık sık beslenme gerekmektedir. Fazla yemekten ise kaçınılmaktadır (47). Reflü için ise reflüjenik besinler olan yüksek yağlı besinler, kızartılmış besinler, asitli içecekler, şeker ilaveli içecekler, çikolata, kahve, baharatlar ve yüksek tuz tüketiminden kaçınmak gerekmektedir. Bunun yanında hızlı yemek, geç saatlerde yemek veya fazla yemek gibi beslenme davranışlarının engellenmesi gerekmektedir (48).

\section{Takip ve Değerlendirme}

2009-2011 yılları arasında 44 SMA Tip 1 hasta bakıcısı üzerinde yapılan anket çalışmasında 43 hastanın beslenme tüpü kullandığı, 34'ünün elemental veya yarı elemental formül kullandığ ve 27 'sinin formül intoleransı sorunu yaşadığı bildirilmiştir. Katılımcıların yarısı kendi başlarına veya diğer ailelerin rehberliğinde beslenme değişiklikleri uyguladığını belirtirken, 15’i bir diyetisyenden yardım aldığını belirtmiştir (49). SMA hastalarının semptomları kısa sürede değişkenlik gösterebildiğinden yakın takip altında olmaları gerekmektedir. Beslenme tedavisi hastaların yaşam kalitesinin arttırılması ve özellikle solunum sıkıntılarının engellenmesi için alanında uzman diyetisyenler tarafından değerlendirilmeli ve gerekirse güncellenmelidir. Küçük çocukların beslenme programının en az 3-6 ayda bir, daha büyüklerin ise yllda bir defa diyetisyen kontrolünden geçmesi gerekmektedir (9). SMA hastalarının tıbbi beslenme tedavisi ve yönetimi için gerekli algoritma Şekil 1'de verilmiştir $(2,3,30,34,38)$.

\section{SONUÇ}

SMA hastalarının tüm türlerinde beslenme sorunları gözlenmektedir. Bu sorunlar hastalı̆̆ın tedavisini olumsuz etkilemekte hastanın ve bakıcısının yaşam standartlarını düşürmektedir. SMA hastalarında beslenme ile ilgili yapılan çalışmaların sayısı oldukça sınırlıdır. Olan çalışmalar da beslenme sorunları ve bu sorunların neden olduğu sonuçları belirtmektedir. Hastalarda uygulanabilecek diyet 


\section{Spinal Musküler Atrofi (SMA) Hastalarında Tıbbi Beslenme Tedavisi Yönetimi}

Detaylı anamnez al.
Bebeğin kişisel bilgileri
Yakınmaların öyküsü
Prenatal, perinatal ve postnatal dönemi kapsayan öykü
Geçirdiği hastalıklar
Büyüme ve gelişme durumu, Beslenme durumu,
Beslenme davranışları
Bakıcının gözlemlerini

Makrobesin ögesi gereksinimlerini sağla

\begin{tabular}{|l|l|}
\hline Protein & Vücut ağırlı̆̆ başına 1-2 gramdır (1-2 g/ $/ \mathrm{kg}$ ) \\
\hline Yağ & $\begin{array}{l}\text { Toplam kalorinin \%30'u yağlardan gelecek } \\
\text { şekilde olmalıdır. }\end{array}$ \\
\hline $\begin{array}{l}\text { Karbon } \\
\text { hidrat }\end{array}$ & $\begin{array}{l}\text { Protein ve yağdan sonra geri kalan enerji } \\
\text { karbonhidrattan sağlanmalıdır. }\end{array}$ \\
\hline Lif & $\begin{array}{l}\text { Yaş artı } 5 \text { 'tir (3 yaşında bir çocuk günde 3+ } \\
5=8 \text { gram life ihtiyaç duyar) }\end{array}$ \\
\hline Su & $115-135 \mathrm{ml} /{ }^{\prime}$ dir. \\
\hline
\end{tabular}

\section{Beslenme yolunu seç.}

Anne sütü alımını her zaman destekle.

Oral alabilen bebeklerde devam et. Takip et.

Ağızdan yeterli alım yoksa enteral beslenme düşün. (Solunumu değerlendir)

Gastrostomi gerekliyse uygula (Nissen fundoplikasyonu reflüyü azaltır)

Enteral yol yetmiyorsa parenteral yol düşün.

\section{Gerekliyse takviye kullan.}

Laboratuvar bulgularına göre vitamin ve mineral eksikleri varsa takviye et. Özellikle D vitamini ve kalsiyum eksikliği görülebilir.

\section{Beslenme sorunlarını engelle.}

Reflü: Aşıı beslenmeden kaçın. Az az sık sık beslen. Yemek sonrası kafa 30 derece olacak şekilde destekle. Dar elbiselerden kaçın. Gerekirse ilaç tedavisi başla. ileri reflü varlığında Nissen fundoplikasyonu ve gastrostomi düşün.

Yutma Güçlüğü: Yutulması daha kolay olacak zenginleştirilmiş besinleri kullan. Gerekirse yutma terapisi sağla. illeri düzeydeise tüplebesleme düşün.

Aspirasyon: Bebek emzirilirken ya da biberonla beslenirken başı dik tutulur. Besleme sonrası bebeğin gazı çıkartılarak, kusmalara karşı dikkatli olunur. Yemek yerken ve yemekten sonra hasta dik oturtulur. Hastanın sakin bir ortamda, yavaş yavaş beslenmesi sağlanır. Besin içeriği seçimine yumuşak ve sıvı gıdalarla başlanarak, tolerasyon durumuna göre katı besinlere geçilir. Hasta pipet kullanması için teşvik edilir. Kabızlık:Sıvı tüketimini destekle, posa miktarını arttır. ileri durumlarda ilaç tedavisial.

\section{Antropometrik ölçümleri al. Kompozisyonunu Değerlendir.}

Boy, ağırlık ve baş çevresi

Yağsız vücut kütlesi

Vücut yağ kütlesi

Kemik mineral yoğunluğu

Dual enerji X-ışını absorbsiometri (DXA) altın standarttır.

Büyüme ve gelişme eğrileri ile vücut kompozisyonu birlikte yorumlanmalıdır.

\section{Enerji gereksinimi hesapla.}

Solunum desteği almayan hasta

$\mathrm{DMH}(\mathrm{kcal} / \mathrm{gün})=35 \times$ vücut ağırlığı $(\mathrm{kg})+75$

(nusinersen tedavisi varsa) +219

DMH $(\mathrm{kcal} / \mathrm{gün})=6 \times$ sırtüstü uzunluk $(\mathrm{cm})+75$

(nusinersen tedavisi varsa) +10

DMH $(\mathrm{kcal} / \mathrm{gün})=24 \times$ tibia uzunluğu $(\mathrm{cm})+97$

(nusinersen tedavisi varsa) +179

Mekanik ventilasyona bağlı hasta

$\mathrm{DMH}(\mathrm{kcal} / \mathrm{gün})=14 \times$ tibia uzunluğu $(\mathrm{cm})+200$

(nusinersen tedavisi varsa) +190

Gerekliyse beslenme ürününü seç.

Hastalar için kanıtlanmış bir formula önerisi yoktur. Gözleme dayanan öneriler düşük yağlı temel formüllerdir.

Bireysel değerlendirme ile takip et. Ürün tolere edilemezse değiştir.

\section{Beslenmeyi sağla.}

Uzman bir diyetisyen tarafından bireyselleştirilmiş gereksinime göre beslenme programı oluşturun Aile ile birlikte yemek yemeyidestekle.

Yutma fonksiyonlarını düzenli olarak değerlendir. Gerekliyse beslenme yolunu değiştir.

Tüp varsa bakımı ve kontrollerinisağla.

Uzun süreli açlıktan kaçın.

Hipo / hiperglisemiyi düzeltmek için glikoz seviyelerini izleyin.

Yeterli sıvı ve elektrolit alımını sağlayın.

Kabızlıktan korumak için liflibesinler önerin.

Malnutrisyon varlığında zenginleştirilmiş besinler kullanın Obezite varlığında kalori kontrolü sağlayın.

\section{Takip et.}

Hastaların büyüme ve gelişmesini takip et.

Yutma fonksiyonlarını takip et.

Küçük çocuklar için her 3-6 ayda, daha büyükler ise senede bir defa diyetisyen tarafından değerlendirilmeli.

Şekil 1. SMA tıbbi beslenme tedavisi yönetimi $(2,3,30,34,38)$ 
çeşitleri, diyetlerin nasıl uygulanacă̆ içerikleri ile ilgili önerilerde bulunan klinik çalışmalar ise yoktur. Şu an için uygulanan tıbbi beslenme tedavisi hastalığın tipi ile hastanın antropometrik ve biyokimyasal bulgularına dayanan bireyselleştirilmiş genel tedavi yaklaşımıdır. Bu tedavide dikkat edilmesi gereken noktalar SMA hastası çocukların enerji gereksinimleri ile büyüme ve gelişme hızlarının sağlıklı çocuklara göre farklı olduğudur. Bu nedenle tedavide rutin formüller ve büyüme gelişme eğrilerinin kullanılması fazla gereksinim göstererek obeziteye neden olabilmektedir. Hastalar için geliştirilmiş özel formüller ile gereksinimlerin hesaplanması gerekmektedir. Aynı zamanda hastalarda yaygın görülen sorunlar nedeniyle enteral beslenme oldukça önemlidir. Bu konuda bakıcılara uzmanlar tarafından iyi eğitim verilmeli yetersiz veya fazla beslenmeden hastalar korunmalıdır. Hastanın doğru değerlendirilebilmesi ve sürecin iyi yönetilebilmesi için de tedavi sürecinde multidisipliner bir ekip ve bu ekipte bir diyetisyenin bulunması gerekmektedir. SMA hastalarında beslenme sorunları oldukça yaygın ve beslenme konusu hastalığın seyrini etkilemede bu kadar önemli olmasına rağmen klinik çalışmaların oldukça sınırlı olması bu alanda acil kapsamlı çalışmalara ihtiyaç olduğunu göstermektedir. Bu derleme ülkemizde SMA ve beslenme konusu üzerine yazılmış ilk çalışmadır.

Hakem Değerlendirmesi: Dış bağımsız.

Peer Review: Externally peer-reviewed.

Çıkar Çatışması: Yazar çıkar çatışması beyan etmemiştir.

Conflict of Interest: Author declared no conflict of interest.

Finansal Destek: Yazarlar finansal destek beyan etmemiştir.

Financial Disclosure: Author declared no financial support.

\section{KAYNAKLAR}

1. Mercuri E, Bertini E, Iannaccone ST. Childhood spinal muscular atrophy: controversies and challenges. Lancet Neurol 2012;11(5):443-52.
2. Munsat TL, Davies KE. International SMA consortium meeting. (26-28 June 1992, Bonn, Germany). Neuromuscul Disord 1992;2:423-8.

3. Wang CH, Finkel RS, Bertini ES, Schroth M, Simonds A, Wong B, et al. Consensus statement for standard of care in spinal muscular atrophy. J Child Neurol 2007;22(8):1027-49.

4. Lally C, Jones C, Farwell W, Reyna SP, Cook SF, Flanders WD. Indirect estimation of the prevalence of spinal muscular atrophy Type I, II, and III in the United States. Orphanet J Rare Dis 2017;12(1):1-6.

5. Lefebvre S, Bürglen L, Reboullet S, Clermont $\mathrm{O}$, Burlet $\mathrm{P}$, Viollet L, et al. Identification and characterization of a spinal muscular atrophydetermining gene. Cell 1995;80(1):155-65.

6. Wirth B, Herz M, Wetter A, Moskau S, Hahnen E, Rudnik-Schöneborn S, et al. Quantitative analysis of survival motor neuron copies: identification of subtle SMN1 mutations in patients with spinal muscular atrophy, genotype-phenotype correlation, and implications for genetic counseling. Am J Hum Genet 1999;64(5):134056.

7. Calucho M, Bernal S, Alias L, March F, Vencesla A, Rodrigues-Alveres FJ, et al. Correlation between SMA type and SMN2 copy number revisited: an analysis of 625 unrelated Spanish patients and a compilation of 2834 reported cases. Neuromuscul Disord 2018;28(3):208-15.

8. Wirth B, Garbes L, Riessland M. How genetic modifiers influence the phenotype of spinal muscular atrophy and suggest future therapeutic approaches. Curr Opin Genet Dev 2013;23(3):330-8.

9. Canpolat M, Bayram AK, Bahadır O, Hüseyin PER, Gümüş $H$, Dundar $M$ et al. Spinal musküler atrofi olgularının klinik özellikleri. J Curr Pediatr 2016;14(1):18-22.

10. Dangouloff T, Servais L. Clinical evidence supporting early treatment of patients with spinal muscular atrophy: current perspectives. Ther Clin Risk Manag 2019;15:1153-61.

11. Mercuri E, Darras BT, Chiriboga CA, Day JW, Campbell C, Connolly AM, et al. Nusinersen versus sham control in later-onset spinal muscular atrophy. N Engl J M 2018;378(7):62535. 
12. Darras BT, Chiriboga CA, Iannaccone ST, Swoboda KJ, Montes J, Mignon L, et al. Nusinersen in later-onset spinal muscular atrophy: long-term results from the phase $1 / 2$ studies. Neurology 2019;92(21):e2492-e506.

13. Pane M, Coratti G, Sansone VA, Messina S, Bruno C, Catteruccia $M$, et al. Nusinersen in type 1 spinal muscular atrophy: Twelve-month real-world data. Ann Neurol 2019;86(3):443-51.

14. Avexis. What is ZOLGENSMA? Published 2019 (cited $2021 \mathrm{Feb}$ 1) Available from: https://www. zolgensma.com/what-is-zolgensma.

15. Sproule DM, Hasnain R, Koenigsberger D, Montgomery M, De Vivo DC, Kaufmann P. Age at disease onset predicts likelihood and rapidity of growth failure among infants and young children with spinal muscular atrophy types 1 and 2. J Child Neurol 2012;27(7):845-51.

16. Heul AMB, Cuppen I, Wadman RI, Asselman F, Schoenmakers MAGC, van de Woude DR, et al. Feeding and swallowing problems in infants with spinal muscular atrophy type 1 : an observational study. J Neuromuscul Dis 2020;7(3):323-30.

17. Wadman RI, van Bruggen HW, Witkamp TD, Sparreboom-Kalaykova SI, Stam M, van den Berg LH, et al. Bulbar muscle MRI changes in patients with SMA with reduced mouth opening and dysphagia. Neurology 2014;83(12):1060-66.

18. Mehta NM, Newman H, Tarrant S, Graham RJ. Nutritional status and nutrient intake challenges in children with spinal muscular atrophy. Pediatr Neurol 2016;57:80-3.

19. Zhou Y, Chen J, Gong X, Lu Z, Hua H, Zhu X, et al. Nutrition status survey of type 2 and 3 spinal muscular atrophy in Chinese population. Nutr Neurosci 2021;1-7.

20. Chen YS, Shih HH, Chen TH, Kuo CH, Jong YJ. Prevalence and risk factors for feeding and swallowing difficulties in spinal muscularatrophy types II and III. J Pediatr 2012;160(3):447-51.

21. Mercuri E, Finkel RS, Muntoni F, Wirth B, Montes J, Main $\mathrm{M}$, et al. Diagnosis and management of spinal muscular atrophy: part 1 : recommendations for diagnosis, rehabilitation, orthopedic and nutritional care. Neuromuscul Disord 2018;28(2):103-15.
22. Messina S, Pane M, De Rose P, Vasta I, Sorleti D, Aloysius A, et al. Feeding problems and malnutrition in spinal muscular atrophy type II. Neuromuscul Disord 2008;18(5):389-93.

23. Romano C, Van Wynckel M, Hulst J, Broekaert I, Bronsky J, Dall'Oglio L, et al. European Society for Paediatric Gastroenterology, Hepatology and Nutrition guidelines for the evaluation and treatment of gastrointestinal and nutritional complications in children with neurological impairment. J Pediatr Gastroenterolog Nutr 2017;65(2):242-64.

24. Poyraz T, Demir S. Çocuklarda nörolojik öykü alma ve muayene. In: Erdoğan F, Demir S, Poyraz T, editors. Süt Çocuğu ve Çocuklarda Nörolojik Değerlendirme. İstanbul: Galenos Yayınevi; 2018.p.1-6.

25. Sproule DM, Montes J, Montgomery M, Battista V, Koenigsberger D, Shen W, et al. Increased fat mass and high incidence of overweight despite low body mass index in patients with spinal muscular atrophy. Neuromuscul Disord 2009;19(6):391-6.

26. Kaufmann P, McDermott MP, Darras BT, Finkel RS, Sproule DM, Kang PB, et al. Prospective cohort study of spinal muscular atrophy types 2 and 3. Neurology 2012;79(18): 1889-97.

27. Sproule DM, Punyanitya M, Shen W, Dashnaw $\mathrm{S}$, Martens B, Montgomery M, et al. Muscle volume estimation by magnetic resonance imaging in spinal muscular atrophy. J Child Neurol 2011;26(3):309-17.

28. Vai S, Bianchi ML, Moroni I, Mastella C, Broggi F, Morandi L, et al. Bone and spinal muscular atrophy. Bone 2015;79:116-20.

29. Sproule DM, Montes J, Dunaway S, Montgomery M, Battista V, Koenigsberger D, et al. Adiposity is increased among high-functioning, nonambulatory patients with spinal muscular atrophy. Neuromuscul Disord 2010;20(7):44852.

30. Moore GE, Lindenmayer AW, McConchie GA, Ryan MM, Davidson ZE. Describing nutrition in spinal muscular atrophy: A systematic review. Neuromuscul Disord 2016;26(7):395404. 
31. Cutillo L, Pizziconi C, Tozzi AE, Verrillo E, Testa $\mathrm{MBC}$, Cutrera R. Predicted and measured resting energy expenditure in children with spinal muscular atrophy 2. J Pediatr 2014;164(5):122830.

32. Bertoli S, De Amicis R, Mastella C, Pieri G, Giaquinto E, Battezzati A, et al. spinal muscular atrophy, types I and II: What are the differences in body composition and resting energy expenditure?. Clin Nutr 2017;36(6):1674-80.

33. Baranello G, De Amicis R, Arnoldi MT, Zanin R, Mastella C, Masson R, et al. Evaluation of body composition as a potential biomarker in spinal muscular atrophy. Muscle Nerve 2020;61(4):530-4.

34. Bertoli S, De Amicis R, Bedogni G, Foppiani A, Leone A, Ravella S, et al. Predictive energy equations for spinal muscular atrophy type I children. Am J Clin Nutr 2020;111(5):983-96.

35. JSCalc.io. (cited 2020 Nov 02). Available from: https://jscalc.io/calc/Q91zp6clkwI9PVBn.

36. Poruk KE, Davis RH, Smart AL, Chisum BS, LaSalle BA, Chan GM., et al. Observational study of caloric and nutrient intake, bone density, and body composition in infants and children with spinal muscular atrophy type I. Neuromuscul Disord 2012;22(11):966-73.

37. Deguise MO, Chehade L, Tierney A, Beauvais A, Kothary R. Low fat diets increase survival of a mouse model of spinal muscular atrophy. Ann Clin Transl Neurol 2019;6(11):2340-46.

38. Deguise MO, Baranello G, Mastella C, Beauvais A, Michaud J, Leone A, et al. Abnormal fatty acid metabolism is a core component of spinal muscular atrophy. Ann Clin Transl Neurol 2019;6(8):1519-32.

39. Sproule, DM. General nutrition guidelines for SMA children. (cited 2020 Nov 02). Available from: http://columbiasma.org/docs/living/ General-Nutrition-Guidelines-in-SMANutrition-Handout.pdf.

40. Choi YA, Suh DI, Chae JH, Shin HI. Trajectory of change in the swallowing status in spinal muscular atrophy type I. Int J Pediatr Otorhinolaryngol 2020;130:109818.
41. Schottlaender L, Scoto M, Imbrigiotta N, Davis T, Main M, Munot $P$, et al. Nutritional status of a large cohort of children with spinal muscular atrophy type 2 (SMA2). Neuromuscul Disord 2017;27:S133.

42. Wadman RI, De Amicis R, Brusa C, Battezzati A, Bertoli S, Davis T, et al. Feeding difficulties in children and adolescents with spinal muscular atrophy type 2. Neuromuscul Disord. 2021;31(2):101-12.

43. Van den Engel-Hoek L, Erasmus CE, Van Bruggen HW, De Swart BJM, Sie LTL, Steenks $\mathrm{MH}$, et al. Dysphagia in spinal muscular atrophy type II: more than a bulbar problem? Neurology 2009;73(21):1787-91.

44. Bowerman M, Swoboda KJ, Michalski JP, Wang GS, Reeks C, Beauvais A, et al. Glucose metabolism and pancreatic defects in spinal muscular atrophy. Ann Neurol 2012;72(2):25668.

45. Davis RH, Miller EA, Zhang RZ, Swoboda KJ. Responses to fasting and glucose loading in a cohort of well children with spinal muscular atrophy type II. J Pediatr 2015;167(6):1362-8.

46. Demir N. Pediatrik nöromusküler hastalıklarda yutma rehabilitasyonu. Karaduman AA, editör. Nöromusküler Hastalıklarda Fizyoterapi ve Rehabilitasyon. 1. Baskı. Ankara: Türkiye Klinikleri, 2020. p.82-8.

47. Müftüoğlu S. Akalazyada beslenme. Güncel Gastroenteroloji 2016;20(3):201-3.

48. Kürklü N, Kaner G. Gastroözofageal reflü hastalığında beslenmeye güncel bakış. Güncel Gastroenteroloji 2015;19(3):139-41.

49. Davis RH, Godshall BJ, Seffrood E, Marcus M, LaSalle BA, Wong B, et al. Nutritional practices at a glance: spinal muscular atrophy type I nutrition survey findings. J Child Neurol 2014;29(11):1467-72. 